\title{
火災救助活動におけるロボット技術活用を想定したシナリオ検証
}

\author{
渡 邊 彩 夏*1 三 浦 洋 靖*2 奥 川 雅 之*2 畑 中 錦 也*3
}

\section{Scenario Verification for the Use of Robots in Fire-Fighting and Rescue Activities}

Ayaka Watanabe $^{* 1}$, Hiroyasu Miura*2 ${ }^{* 2}$ Masayuki Okugawa*2 and Kinya Hatanaka*3

\begin{abstract}
This paper describes about activities for the cooperative exercise by Aichi Institute of Technology and Toyota city Fire Department in order to aim at the effective utilization of the disaster response robot in the search and rescue activities on fire. The scenario verification which clarified each role sharing between the robot and the responders, the cooperative exercise results and the lesson learned show the effectiveness of the remote controlled robot at the initial response of search and rescue activities, e.g., the poisonous/flammable gas concentration measurement and the victim search and the door control in closed and confined spaces such as concrete buildings. Discussions on cooperative exercise are important opportunity for understanding and sharing issues about problems in the disaster scene and the robot performance and feature.
\end{abstract}

Key Words: Cooperative Exercise, Disaster Response Robot, Search and Rescue, Underground Fire, Scenario

\section{1.は じめに}

人口が集中している都市部での風水害や大規模地震などの自 然災害や火災／交通事故や爆弾テロなどの人的災害の発生に対 して，倒壊建物や地下街のような狭险閉鎖空間や石油化学／製 造プラントのような可燃性ガスの漏洩が問題となる場所では, 迅速な被害状況調査，人命検索や環境測定など都市型捜索救助 技術が消防隊に必要とされる。そのような二次災害の発生の可 能性が高い環境下で消防隊員の安全を守ることも重要な課題と なる。一つの解決策として, 遠隔操縦型移動ロボットによる調 査救助活動の支援が期待されている。2001 年 9 月 11 日に発 生した NY 同時多発テロ事件後, CRASAR（The Center for Robot-Assisted Search and Rescue) によるロボットを活用 した人命捜索活動が代表的な活動事例である [1]. それ以降，口 ボットと消防隊員が連携した調査救助活動が注目されている.

2011 年 3 月に日本で発生した東日本大震災によって起きた原 発爆発事故建屋内調査 [2], 2012 年 5 月にイタリア北部のエミ リアロマーニャ地方で発生した地震によって被害を受けた歴史 的建造物の被害調査 [3] などにもロボットが用いられている。 ボット技術による調査救助活動支援の利点の一つは，倒壊の危 険性のある狭险空間内を調査する場合，人の代替として遠隔操 縦型ロボットを現場に投入することで消防隊員は安全な調査活 動が可能なことである．ほかの利点として，有毒ガスや可燃性 ガスの漏洩が予想されるエリアでは, 初動活動として, ロボット

原稿受付 2019 年 10 月 22 日

*1愛知工業大学大学院工学研究科

*2 愛知工業大学

$* 3$ 豊田市消防本部中消防署

${ }^{* 1}$ Graduate School of Engineering, Aichi Institute of Technology

${ }^{* 2}$ Aichi Institute of Technology

${ }^{* 3}$ Fire Fighting Head Office in Toyota

口本論文は有用性（実証実験分野）で評価されました。
に搭載されたガスセンサで現場周辺をモニタリングが可能とな ることで, 二次災害の発生を避けられるといったことが挙げら れる。これらの利点により消防隊員の危険回避や負担軽減が期 待され，ロボット技術に対する消防分野からのニーズが文献 [4] にまとめられている。 また，2008 年時点における日本国内の消 防本部に配備されている消防防災ロボットの中で, 最も多く配 備されているロボットは水中探索型であり活用事例数も多い. しかし, 情報収集型, 救助型, 重量物排除型に関しては現場での 利用実績がないと述べられている[5]. そのような状況の中で, 2019 年 4 月から石油化学コンビナートなどの大規模火災や爆 発に対する偵察や監視と放水を行うロボットシステムが千葉県 市原市に配備され, 実戦での利用が期待されている [6]. 欧米で は，ロボットと消防隊員との連携を目指したシナリオをもとに した訓練事例 [7] やプロジェクト提案はいくつか報告されてい る [8]〜 [11]. しかし，日本では，ロボット開発者や研究者と消 防隊員がともに連携し，シナリオを想定した合同訓練を実施し た事例は少ない $[12]$.

筆者らは，2013 年に豊田市と愛知工業大学が結んだ包括連携 協定に基づき, 2015 年から豊田市消防本部中消防署と愛知工業 大学知能機械システム工学研究室とによる合同訓練をこれまで に 6 回行ってきた. 本研究プロジェクトでは, ロボットと消防 隊員との協働により, 火災発生現場での調査救助活動における 消防隊員のリスク低減の実現を目指している．特に，消防隊員 が現在のロボット技術レベルを把握するとともに, ロボット研 究者や開発者が, 現場での調査救助活動の実態を理解し, それ らを共有することによって，人とロボットに適した役割分担を 考えた救助シナリオの作成を試みている.

本論文は，日本国内に抒けるシナリオベースの合同訓練の事 例として, コンクリート建屋内（シナリオ A 地下空間：2017 年 12 月, シナリオ B2 階： 2019 年 3 月）での火災を想定した訓 練の概要と得られた知見について述べる. 


\section{2. 調査ロボット "Scott"}

本訓練に使用した災害対応調査ロボット Scott（Fig. 1）は， 全長 $720[\mathrm{~mm}]$, 幅 $390[\mathrm{~mm}]$, 高さ $200[\mathrm{~mm}]$ (マニピュレータ 搭載時: $330[\mathrm{~mm}]$ ), 重量は約 $23[\mathrm{~kg}]$ （搭載物を除く）であり, 2 リンクマニピュレータと前後左右に 4 本のサブクローラを有 するクローラ型移動ロボットである．段差踏破時の重心移動を 補完するサブクローラの回転軸がフリージョイント（劣駆動） になっている点を特徵とする 13$]$. 高い機構自由度を有してい るが，機構が有する対地適応性により操縦者は複雑な各サブク ローラ操作を行う必要はなく，進行方向および移動速度の指示 のみで不整地を移動させ調査対象エリアまで到達させることが できる、ロボットアーム先端には，カメラや各種測定器を搭載 することが可能である。また，制御および通信部として，サン リツオートメイション社製の TPIP システムを搭載しており, 無線／有線 LAN 通信によるロボットの遠隔制御やセンサ情報 の取得やカメラ画像拈よび音声の送信を行っている，社会イン フラノプラントの点検調査や災害対応を目的とした実用化プロ ジェクトを企業と共同で行っている.

操縦用カメラ 4 台 (可視光 3 台 赤外線 1 台), 調査用カメラ 1 台 (可視光カメラ), $\mathrm{CO}_{2}$ センサ, 温度センサ, 熱画像カメラ (FLIR AX8), ガス濃度測定器 (理研計器 GX-2009), マイク スピーカ（ロボット側と操縦側との音声通信が可能）を搭載して いる.レーザレンジファインダ (北陽電機 UST-20LX, 検出距 離: $20[\mathrm{~m}]$, 走査角度: 270 度)により $2 \mathrm{D}$ SLAM が可能である. ロボットと操縦システムとの通信については，無線通信で接続 される調査ロボットと有線ケーブルドラムを搭載したケーブル 敷設ロボットの 2 台体制で実施する場合を通信パターン 1 とし, 調査ロボットを直接有線通信で接続する通信パターン 2 の 2 パ ターンでの運用が可能であり，有線 LAN ケーブル $(60[\mathrm{~m}])$ を 使用した（以降，通信パターン 1 を「ハイブリッド通信」，通信 パターン 2 を「有線通信」とよぶ)。有線ケーブルドラムは，口 ボットの移動速度に応じて能動的にケーブルの送出および巻取 制御が可能である。また，LiDAR（北陽電機 YVT-35LX，検 出距離: $35[\mathrm{~m}]$, 走査角度 : 水平 210 度 /垂直 40 度）を搭載し, $3 \mathrm{D}$ 空間計測を試行した.

\section{3. 消防隊員との事前ディスカッション}

2015 年から 2017 年 2 月までの間に豊田消防署と愛知工業大 学知能機械システム工学研究室と連携し, 地下火災や狭隘空間 での捜索／救助などを想定した調査救助活動シナリオに基づい た合同訓練を 4 回実施した。合同訓練を実施する際，大学側か

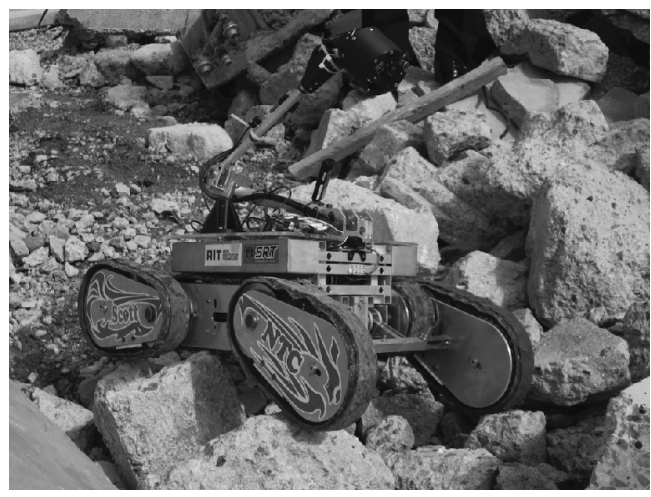

Fig. 1 Scott
らはロボットのデモ実施や技術説明を行うとともに，消防隊員 からは災害時の調査救助活動の手順や課題などに関するディス カッションを通して, 消防隊員とのロボット技術の現状や課題 共有を試みている，その中で，以下に関する事項について消防 隊員からロボットの優位性を認められた。

- Scott が比較的小型であり閉鎖狭盆空間での調査に適している

-未知空間での環境地図が作成できる

・熱画像カメラやガスセンサの活用が可能である

・有線通信ケーブルは, 消防隊進入時のガイドに有効である しかし，一方で，次の事項に関して要求が挙がった.

一消防隊員が現場に進入する際，既設の通信ケーブルが活動障 害になってしまう（ケーブルを踏みそうになるなど）

一消防隊員の活動において現場空間の高さ，通路幅，要救助者 までの距離などの正確な情報が必要

一ロボット操縦者と消防隊員とのコミュニケーションが不足 (取 得可能な情報と知りたい情報との共通認識が不足)

第 5 回合同訓練では，地下空間での行方不明者の捜索を想定 したシナリオを用意した。

第 6 回合同訓練では, 簡単な軽作業を想定し, マニピュレー 夕先端部にハンドを実装した。その用途について消防隊員と議 論し，火災発生箇所を 2 階とし，火災拡散防止を想定したドア コントロールを取り入れたシナリオを用意した。

\section{4. 訓練シナリオ $\mathrm{A}$ : 地下火災}

\section{1 シナリオと評価項目}

第 5 回合同訓練は, 以下のシナリオを設定し, 2017 年 12 月 5 日に実施された。

「地下倉庫内で火災が発生し, 可燃性ガス漏れによる爆 発の危険が高く, 二次災害の発生が懸念されることか ら消防隊員の進入が困難になった。 また，行方不明者

二名，施設内部は暗所でありレイアウトも不明である」 火災現場は，豊田市消防本部中消防署訓練塔地下 1 階に用意 した. 階段を降りてすぐの場所に一つめの部屋があり, さらに 進入すると二つめの部屋がある（Fig. 2)，それぞれの部屋の電 気は消えており，外からの光も遮断されている．また，それぞ れの部屋には要救助者役の消防隊員がいる，本訓練ではロボッ 卜を用いて要救助者を探し, 場所を特定する。 その後，ロボッ トの情報をもとに消防隊員によって救出および消火活動を行う. ロボットの操縦は, 操縦経験のある本研究室の学生が行った. 操縦者には，訓練シナリオのみを伝え，建物内の間取りや状況 など事前情報は伝えていない，また，使用したロボットは防爆 仕様があるものと仮定して訓練を行った。

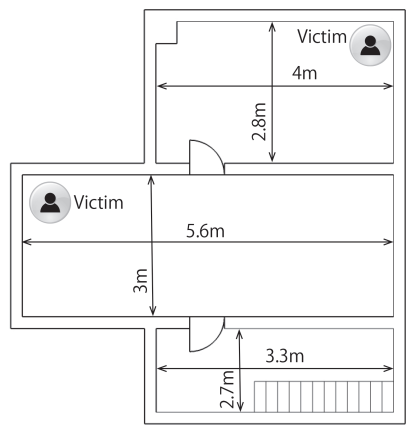

Fig. 2 Room layout for the underground floor of Toyota FD training tower 


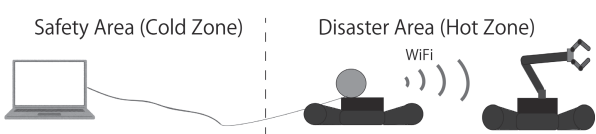

Fig. 3 CASE 1 (Hybrid): Network communication configuration between robots and operation system

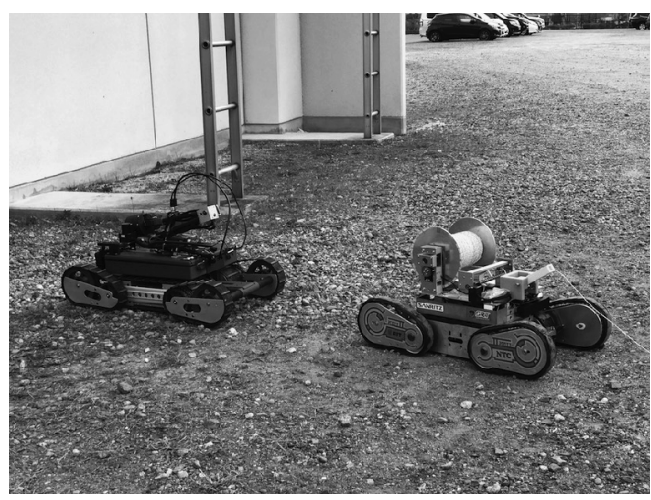

(a) Scene of moving robots (search and cable laying) in a row

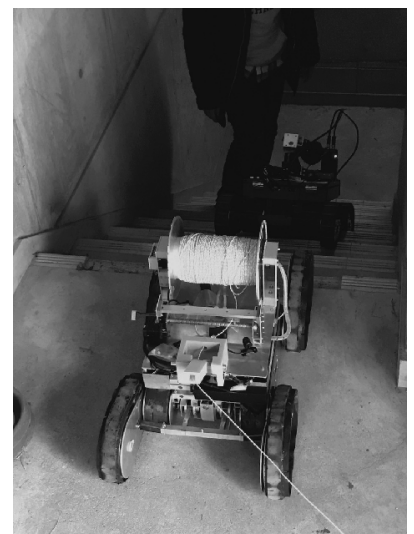

(b) Scene of robots going down stairs

Fig. 4 Approach process of scenario A (at Toyota FD training tower, Dec. 5th, 2017)

消防隊員との事前ディスカッションをもとに，第 5 回訓練に おける検証内容は以下の 4 点とした.

E1A ロボットに搭載されたカメラ映像や熱画像カメラなどの 情報の活用による要救助者発見に対する迅速性

E2A ロボットにより作成された環境地図をもとにした地下空 間のレイアウト把握の可否および消防隊員の進入計画への活用 可否

E3A ロボットの通信ケーブルを消防隊員の進入ガイドとして 活用できるかどうか

E4A ロボットのカメラ映像をもとに隊員の活動状況の監視に よる消防隊員の安全管理の可否, 現場指揮本部から危険の周知 や助言の実現

\section{2 シナリオ $\mathrm{A}$ : 結果と考察}

訓練で使用する建屋はコンクリートで作られており，地下空 間での活動になることから，Fig. 3 に示すような通信パターン 1 のハイブリッド通信を採用し, 通信ケーブル敷設ロボットと 調査ロボットの 2 台体制での調査活動を試みた [14]. Fig. 4 に 訓練の様子を示す.

予定していた調查や人命捜索，環境情報測定などおおむね良 好に行うことができた．以下にシナリオの検証事項に関する結 果と考察を述べる.

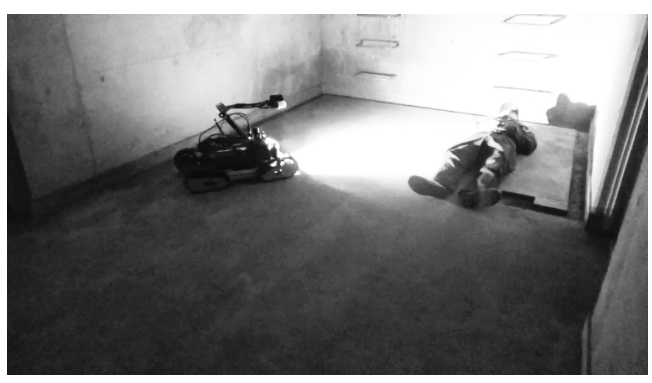

(a) Detection of victim by search robot

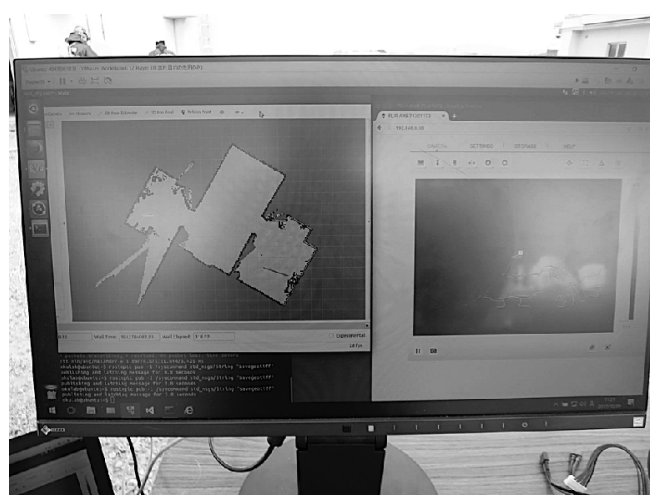

(b) Thermo camera image for victim and 2D local map

Fig. 5 Search and rescue process (1) of scenario A (at Toyota FD training tower, Dec. 5th, 2017)

\subsubsection{E1A：要救助者発見に対する迅速性}

Fig. 5 に示すように，ロボットに搭載された照明や熱画像カ メラにより, 暗所の中, 要救助者を発見することに成功すると ともに，2D 環境地図をリアルタイムに作成することで，要救 助者の位置をマッピングし，消防隊員に明示することができた. 2 名の要救助者の発見および環境地図構築までに要した時間は 8 分であった。活動時間内に消防隊進入経路の安全性確認, 環 境地図の提示, 要救助者の有無と場所を消防隊員に示すことが できた，消防隊員から，ロボットの活用により安全で迅速な活 動が十分に実現できたとの意見を得た。

$4.2 .2 \mathrm{E} 2 \mathrm{~A}$ ：環境地図活用（地下空間把握执よび進入計画） 間取りが未知な状況の中, 移動しながら逐次 $2 \mathrm{D}$ 環境地図を 作成し，消防隊員にそれらを示すことにより，空間を把握し，現 場指揮本部にて進入計画に活用することができた $($ Fig. 6 (a)). ただし，煙や蒸気などに対するセンサの対応が必要である.

4.2.3 E3A：通信ケーブル進入ガイド活用

これまでの訓練では, 調査ロボットが有線通信であったため, 有線 LAN ケーブルを引きずりながらの調査を行っており， ロ ボットが調査を行う際にロボット自身でケーブルを踏みクロー ラ部に巻き込まないように注意を払いながら調査活動を行って いたが，敷設ロボットを導入したハイブリッド通信システムに より，調査ロボットは，通信ケーブルを気にせず要救助者の捜 索や環境測定などの調査活動が行いやすくなった [14]. 一方で, 消防隊員は要救助者が発見された場所まで通信ケーブルに沿っ て移動することができたため，進入ガイドとして通信ケーブル を活用することは有効であるとの意見を得た．しかし，消防隊 員の動線上に通信ケーブルがあるため，ケーブルの視認性や耐 久性の向上，配置する場所を考慮する必要がある.

\subsubsection{E4A 活動状況監視}

Fig. 6 (b) に示すように，消防隊が現場に到着後，調査ロボッ 


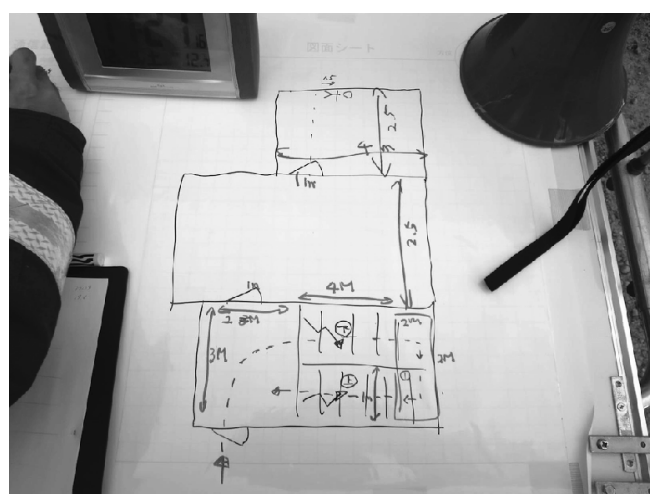

(a) Victim position and room layout on the real time creating map by information from search robot

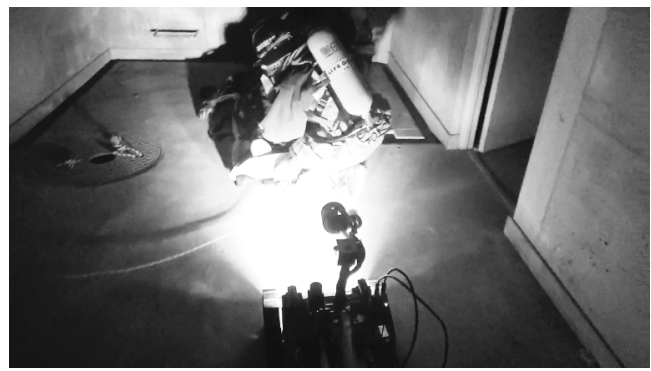

(b) Cooperation activity example of responder and robot: Video image support by robot

Fig. 6 Search and rescue process (2) of scenario A (at Toyota FD training tower, Dec. 5th, 2017)

卜は少し後方に下がり，カメラ映像を現場指揮本部のモニ夕に 表示し活動状況をモニタリングすることで，現場指揮者は現場 の様子を逐次確認することができ，調査ロボットの音声通信機 能を利用して，適切な指示を現場の隊員に伝えることが可能で あった.しかし, 操縦者としては, 消防隊が今必要としている 情報が分からない，消防隊としては，ロボットによってどんな 情報が得られるのかが分からないという意見があり，情報提示 方法やコミュニケーション方法を検討する必要がある.

\section{5. 訓練シナリオ $\mathrm{B}$ ：耐火建築物火災}

\section{1 シナリオと評価項目}

第 6 回合同訓練は，以下のシナリオを設定し，2019 年 3 月 10 日に豊田市消防本部中消防署訓練塔にて合同訓練が実施された.

「耐火建造物機械室内電気設備からの出火による火災を

想定 (2 階 2 部屋, 1 名の安否不明者). 施設関係者に

よると建物内にいた人の避難は完了している．作業者

1 名の安否が不明」

火災現場は，豊田市消防本部中消防署訓練塔 2 階に用意した。 階段を登ると一つめの部屋に到達し, さらに進入すると二つの 部屋がある (Fig. 7). それぞれの部屋の電気は消えており, 外 からの光も遮断されている. また, 部屋 $\mathrm{A}$ には要救助者がお り, 部屋 B には火元に見立てたストーブが設置されている. オ ペレータには, 要救助者の捜索と延焼による火災拡散を防ぐた め，ドアコントロール（今回は部屋 B のドアを閉める）の依頼 が伝えられた。 まず, ロボットが階段を登り 2 階に到達後, 要 救助者の捜索および火元の特定を行う. その後, ロボットから の情報をもとに消防隊員によって救出を行い消火活動が行われ る、ロボットの耐熱性に関しては，下方空間の温度は比較的低 いことから対応できる範囲内として訓練を行った。

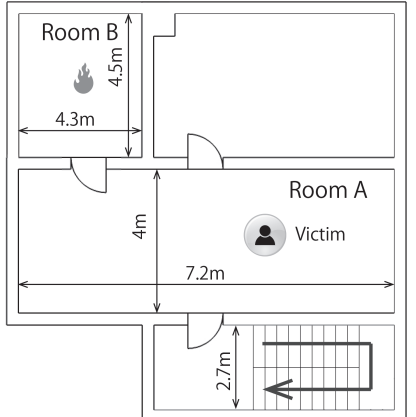

Fig. 7 Room layout for the second floor of Toyota FD training tower

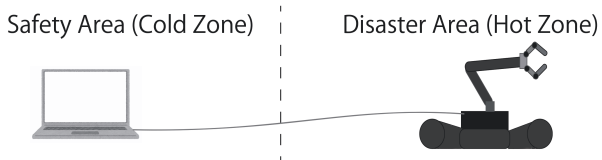

Fig. 8 CASE 2 (Standalone) : Network communication configuration between robots and operation system

前回の訓練でロボット活用の利点として認識された内容を継 続するとともに, 消防隊員との事前ディスカッションをもとに, 第 6 回訓練における検証内容は以下の 3 点とした.

E1B 救助活動プランニングに対する情報提供可否

E2B 階段走破可否

E3B ドアコントロール可否

\section{2 シナリオ $\mathrm{B}$ : 結果と考察}

本訓練シナリオでは, Fig. 8 に示すようにロボットと操縦シ ステムを直接接続したスタンドアローン通信構成とした。また， これまでの知見から，消防隊が任意のタイミングで逐次情報確 認ができるよう別途情報提供用モニ夕を準備し，常に調查情報 を表示するようにした（Fig.9(a)）.

予定していた調査や人命捜索, 環境情報測定, ドアコントロー ルなどおおむね良好に行うことができた，以下にシナリオの検 証事項に関する結果と考察を述べる.

5.2.1 E1B 救助活動プランニングに対する情報提供 消防隊員に随時確認してもらうためのモニ夕を用意したこと により，ロボットから得られた情報をオペレータが消防隊員に 伝達するだけでなく，消防隊員が直接情報を得ることにより，今 得られている情報が何か，ほかにどんな情報が必要かを共有す ることが可能になった，その結果，これまでの訓練に比べ情報 の伝達がスムーズに行え, 操縦用カメラと調査用カメラを分け たことにより消防隊員の見たい映像を提供することが可能とな り,リアルタイムに状況確認のための情報を提供することができ た．消防隊員が消火活動にあたる際には，事前に必ず周辺の温 度やガス濃度の計測を行い安全を確認したうえで救助活動を行 う。本訓練においてもロボットのセンサを用いて，ガス濃度の 計測と現場周辺の温度の計測を行い, 消防隊員の装備のプラン ニングに情報提供ができた．消防隊員が活動を行っている最中 もガス濃度の計測，温度の情報を常に伝達していた。 また，要救 助者に対してロボットから声がけを行うことができ，消防隊員 とともに要救助者の状態を確認することができた (Fig. 9 (b)). しかし, 消防隊員が常時モニ夕に張り付くことは現実的に困難 であるという指摘があった.

5.2.2 E2B 階段走破

第 6 回訓練では，火元が 2 階であるため合同訓練では初めて 


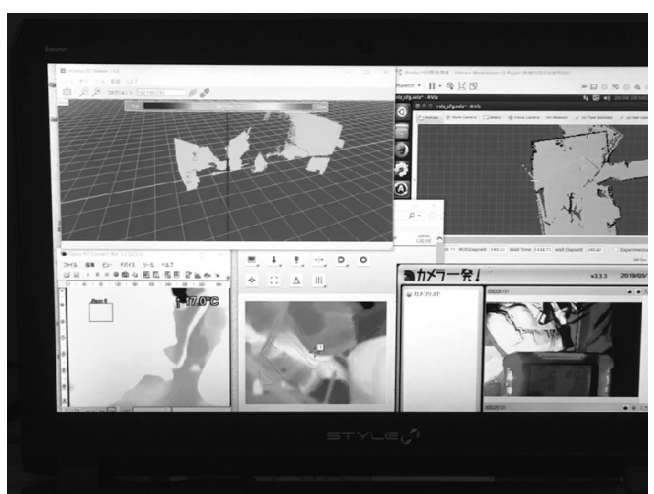

(a) 2D/3D mapping and thermal image

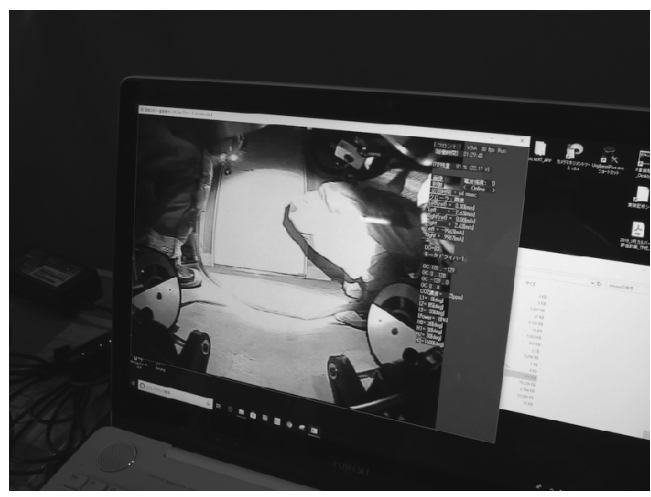

(b) Video image of responder activity at the hot zone from the camera with robot

Fig. 9 Activity support examples: Video image presentation to responders at operation area by using monitor

階段走破を行った（Fig. $10(b))$. 走破対象の階段は，蹴上高 さ約 $21[\mathrm{~cm}]$, 踏み面約 $32[\mathrm{~cm}]$, 段数 18 段, 傾斜約 33 度であ り，消防隊員であれば 5 秒程度で登ることが可能である。しか し，階段のエッジ部分が滑りやすい形状であったため，スリップ が断続的に発生し、ロボットが階段を走破完了するまでに約 10 分の時間を要した．現場に到達できたものの活動時間約 30 分 に対して $33 \%$ の時間を階段走破に費やしてしまったことから， 要救助者発見に対する迅速性を損なう結果となった。

\section{2 .3 E3B ドアコントロール}

延焼を防ぐため，調査ロボットの操作画面に表示された熱画 像カメラ映像により火元の場所を特定したのち, 消防隊員の指示 のもと火元のある部屋 B の扉に対して，ロボットを扉に押し付 けながら押すことで扉を閉めることに成功した（Fig. $11(\mathrm{a})$ ). その後, 消防隊員が現場に到着し，要救助者を救助後，部屋 B 内に要救助者の有無を確認した。ドアコントロールは消火活動 での鉄則であり，延焼および煙の流入を防ぐことで環境の悪化 を防ぐことができ，消防隊員は円滑に救助活動を行うことがで きるため, ロボットによるドアコントロールは重要なポイント となった。 また，火災現場では，フラッシュオーバーやバック ドラフトの危険があるため，ロボットによりドアを開くことが できれば消防隊員の安全性をかなり高めることに寄与すること ができる.

その他に，消防隊員から以下のような助言を受けた。

・実際の火災現場では煙が発生しているので，煙中の移動や調 査に対応することが望ましい.

・ロボットの位置が救助活動の妨げになる場面があり，消防隊 員との密な連絡が必要である.

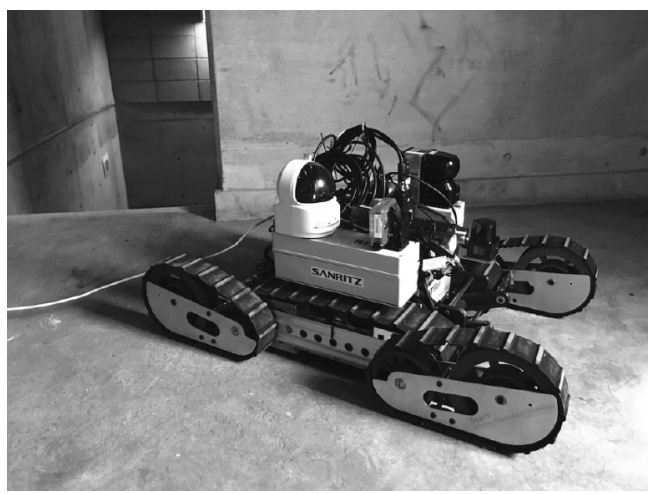

(a) Scott as search robot with wired communication cable

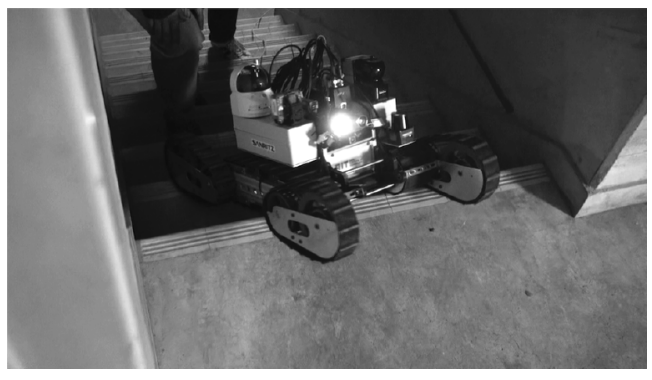

(b) Scene of robots going up stairs

Fig. 10 Approach process of scenario B (at Toyota FD training tower, Mar. 10th, 2019)

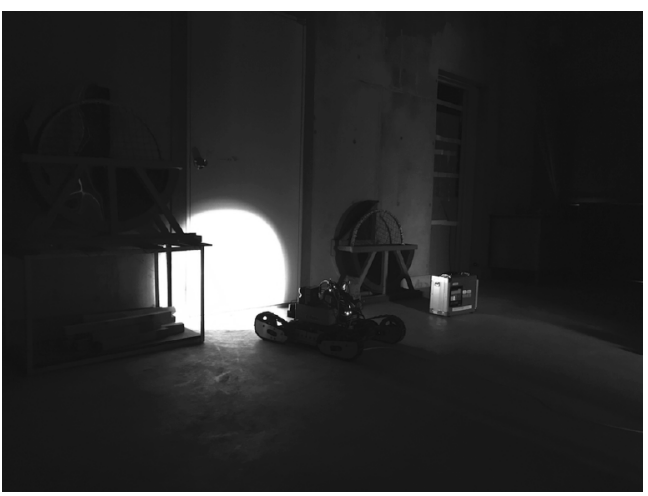

(a) Scene of the robot closing the door to prevent fire spread

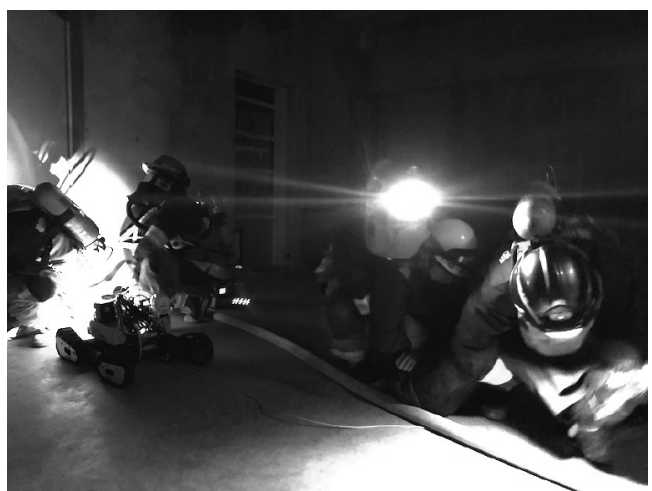

(b) Activity support: Monitoring by using the camera with robot

Fig. 11 Process of scenario B (at Toyota FD training tower, Mar. 10th, 2019)

・活動中や搬送中に消防隊員が通信ケーブルに足を引つ掛ける 可能性があることから，通信ケーブルが暗闇で目立つような工 
夫があると，消防隊員はケーブルを辿りやすいとともにケー ブルが活動を妨げることも防げる.

・暗闇かつ狭い場所での活動のため, Fig. 11(b)のような場面 では, 消防隊員がロボットに接触してしまうことがあるため, ロボットに存在感（音声や光）が必要である.

- 要救助者の捜索や内部の環境測定においては, 高さの低い口 ボットは火災等の影響を受けにくい. その理由として，フラッ シュオーバーやバックドラフトなどの急激な爆燃現象を除く 初期から中期の火災環境において，視界の確保が可能で可視 光カメラによる要救助者の早期捜索や輻射熱の軽減による機 体ダメージ低下などのメリットがあるため, 消防隊員の進入 が困難な環境下でも，高さの低いロボットを投入することが 可能であり，消防隊員に必要な情報提供を実施し，現場活動 の円滑化が可能となる。

\section{6. ま と め}

本論文では，愛知工業大学と豊田消防署との合同訓練に関す るシナリオの説明と得られた知見について述べた。現場での活 動実態やロボットの能力などに関する情報共有を行い，連携訓 練シナリオを作成した，今回の合同訓練結果から，ロボットに よるガス濃度測定や人命捜索, 環境地図作成およびドアコント ロールといった火桨現場での調査救助初動時におけるロボット 活用の有効性が確認された。 しかし, 濃煙時の対策やロボット 取得情報の消防隊員への迅速な提供方法などの課題も顕在化し た．合同訓練は，災害現場での課題抽出やロボットの性能や機 能をそれぞれの立場で理解共有する機会として非常に有効であ る.より多くの訓練シナリオを用意することで，ロボットの活 用方法が具体化されるとともに, 新しい活用法の創出にもつなが る．今後も合同訓練を継続的に実施する予定である．日本国内 では，ロボットを提供する大学や企業と消防や警察などといっ たユーザとの合同訓練の事例は少ない。本プロジェクトとの取 り組みが災害対応ロボットの社会実装への事例となることを望 んでいる.

\section{参 考 文 献}

[1] J. Casper and R.R. Murphy: "Human-Robot Interaction during the Robot-Assisted Urban Search and Rescue Response at the World Trade Center," IEEE Transactions on Systems, Man and Cybernetics, Part B, vol.33, no.3, pp.367-385, 2003.

[2 ] K. Nagatani, et al.: "Redesign of rescue mobile robot Quince," Proc. of the 9th IEEE International Safety, Security and Rescue Robotics (SSRR2011), pp.13-18, 2011.

[3] G. M. Kruijff, et al.: "Rescue Robots at Earthquake-Hit Mirandola, Italy: A field report," Proc. of the 10th IEEE International Symposium on Safety, Security and Rescue Robotics (SSRR2012), pp.1-8, 2012.

[4] 天野久德：“消防防災ロボットとしてのニーズ”, 日本ロボット学会 誌, vol.27, no.3, pp.287-290, 2009.

[ 5 ] 天野久徳：“消防防災ロボットの現状と展望”, 映像情報メディア学会 誌, vol.62, no.9, pp.1391-1395, 2008.

[6]市原市：エネルギー・産業基盤災害に対応する消防ロボットシステム を全国で初めて配備，2019 年 4 月 16 日プレスリリース.

[7] T. Perkins and R.R. Murphy: "Active and Mediated Opportunistic Cooperation Between an Unmanned Aerial Vehicle and an Unmanned Ground Vehicle," Proc. of the 11th IEEE International Symposium on Safety, Security and Rescue Robotics (SSRR2013), pp.1-8, 2013.

[8] N. Ruangpayoongsak, H. Roth and J. Chudoba: "Mobile robots for search and rescue," Proc. of IEEE International Workshop on Safety, Security and Rescue Robotics (SSRR2005), pp.212$217,2005$.

[ 9 ] L. Marconi, et al.: "The SHERPA project: smart collaboration between humans and ground-aerial robots for improving rescuing activities in alpine environments," Proc. of IEEE International Symposium on Safety, Security and Rescue Robotics, pp.1-4, 2012.

[10] R.P. Rocha, et al.: "The CHOPIN project: Cooperation between Human and rObotic teams in catastroPhic INcidents," Proc. of the 11th IEEE International Symposium on Safety, Security and Rescue Robotics (SSRR2013), pp.1-4, 2013.

[11] T. Doi, T. Kinugasa, M. Okugawa, et al.: "Development of Rescue Vest using ICT," Proc. of the 11ht IEEE International Symposium on Safety, Security and Rescue Robotics (SSRR2013), pp.1-5, 2013.

[12] 田所諭：“大都市大震災軽隇化特別プロジェクトの概要”, 第 49 回自 動制御連合講演会論文集, SA1-1-1, 2006.

[13] S. Suzuki, S. Hasegawa and M. Okugawa: "Remote Control System of Disaster Response Robot with Passive SubCrawlers Considering Falling Down Avoidance," Robomech Journal, vol.1, issue 1, p.20, 2014.

[14] A. Watanabe, H. Miura, M. Okugawa and K. Hatanaka: "Verification of Scenario for Robot-Assisted Fire-Fighting and Rescue Operations," Proc. of IEEE International Symposium on Safety, Security and Rescue Robotics (SSRR2019), pp.106-107, 2019.

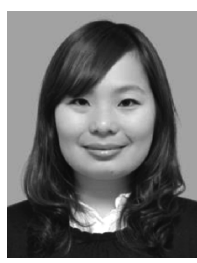

渡邊彩夏 (Ayaka Watanabe)

2015 年愛知工業大学工学部機械学科卒業. 2017 年 愛知工業大学大学院工学研究科機械工学専攻博士前 期課程修了. 同年愛知工業大学大学院工学研究科生 産・建設工学専攻博士後期課程進学, 現在に至る. レスキュー工学に関する研究に従事. 日本機械学会 会員.

(日本ロボット学会学生会員)

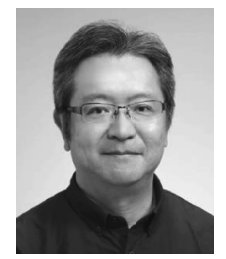

三浦洋靖（Hiroyasu Miura）

1992 年愛知工業大学工学部機械工学科卒業. 同年 愛知電機株式会社に入社, 電力向変電設備機器の生 産設備開発, 製品開発を得て, 2018 年サンリツオー トメイション株式会社に入社し点検調査ロボットお よび各種ロボットの研究開発に従事，現在に至る. 2016 年から愛知工業大学地域防災研究センター客 員研究員を兼務しレスキュー工学に関する研究に従事. 日本機械学会 会員.

（日本ロボット学会正会員）

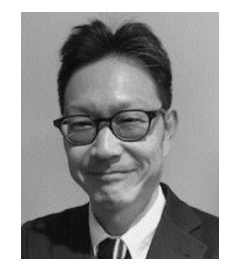

奥川雅之（Masayuki Okugawa）

1996 年岐阜大学大学院工学研究科機械工学専攻博 士前期課程修了．同年岐阜工業高等専門学校機械工 学科助手, 講師, 助教授, 准教授を経て, 2009 年 愛知工業大学工学部機械学科准教授, 2017 年同教 授，現在に至る。レスキュー工学拉よびスマート構 造等に関する研究に従事. 日本機械学会, 計測自動 制御学会, IEEE，ASTM 等各会員. 博士 (工学).

(日本ロボット学会正会員)

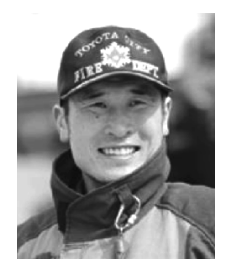

畑中錦也（Kinya Hatanaka）

2003 年愛知工業大学工学部土木工学科卒業. 同年 豊田市消防本部入庁, 2009 年高度救助隊員として勤 務, 2011 年東日本大震災緊急消防援助隊派遣, 2013 年名古屋市消防局に出向派遣， 2015 年高度救助隊 員として再度勤務，現在に至る. 消防職員として， 火災抢よび救助 (水・陸) の分野に従事し，技術を習 得するとともに, 現在は北消防署救助警防担当で小隊長として活動. 